\title{
OPEN ROUND TABLE OF MUSEOLOGY: INTERNATIONAL LIVE DISCUSSION OF STUDENTS AND EXPERTS ON MUSEOLOGY
}

\author{
BERNADETTE BIEDERMANN - LENKA MRÁZOVÁ
}

The rebirth of active student engagement and motivation in the theory of museology and its connection to museum practice is the goal of all museology studies worldwide. Active and critical thinking is of utmost importance for students as future active and engaged museum professionals with real interest in museum work and its connection to society.

Museology as a vivid discipline is interesting and important for the work of museum professionals and for students - future museum professionals. An open and critical debate, sharing of ideas, forum for youth thinking as well as support to international scientific contacts are therefore the basics. This includes safe, warm and really personal meetings of young generation, museology students and their teachers, as well as a place for meeting of academic and museum practice. These ideas created the base of the first Open Round Table of Museology held by two universities with strong museology tradition. The Centre of Museology at Masaryk University in Brno ${ }^{1}$ is one of the oldest permanent museological departments worldwide, which is linked inextricably with the personality of Zbyněk Z. Stránský ${ }^{2}$ the

1 Official homepage - see Dept of Archaeology and Museology - the Museology Section [online]. Masaryk University, Faculty of Arts [cit. 2017-03-14]. Available from www: <http://www. phil.muni.cz/waom/index_html-en/view?set language $=\mathrm{en}>$.

2 On his influences on international museological thinking see Museologica Brunensia, 2016, vol. 5, no. 2 . leading figure and founder of basic museological concepts of museality and musealisation. Therefore the „Brno school of museology“ helped to form the basis of the discipline and contributed to the professionalization of museum work. This is why museology is a discipline with a long-time tradition in the Czech Republic. In 1994, the UNESCO Chair of Museology and World Heritage ${ }^{3}$ was established at the Masaryk University as one of the oldest UNESCO Chairs worldwide which also is the only one focused on museology. It is connected with another important name of world museology, Vinoš Sofka, ${ }^{4}$ who was the founder of the Chair as well as its first Chair holder. The above personalities took part in the founding of international organisations like ICOFOM and International Summer School of Museology (ISSOM) providing for wide platforms where international cooperation in the field of museology was established and intensified. This basis and the concept of the museology system were further developed and deepened by the Austrian museologist Friedrich

\footnotetext{
3 Official homepage - see UNESCO Chair of Museology and World Heritage [online]. Masaryk University, Faculty of Arts [cit. 2017-03-14]. Available from www: <http://www.phil.muni.cz/ wune/index_html-en/view?set_language $=e n>$.

4 About this personality see in brief NASH, Susanne. The UNESCO Chair of Museology and World Heritage: Mrs. Suzanne Nash's memories of the origins of the UNESCO Chair of Museology and World Heritage and of the first UNESCO Chair holder Vinoš Sofka. Museologica Brunensia, 2015, vol. 4, no. 2, pp. 72-73.
}
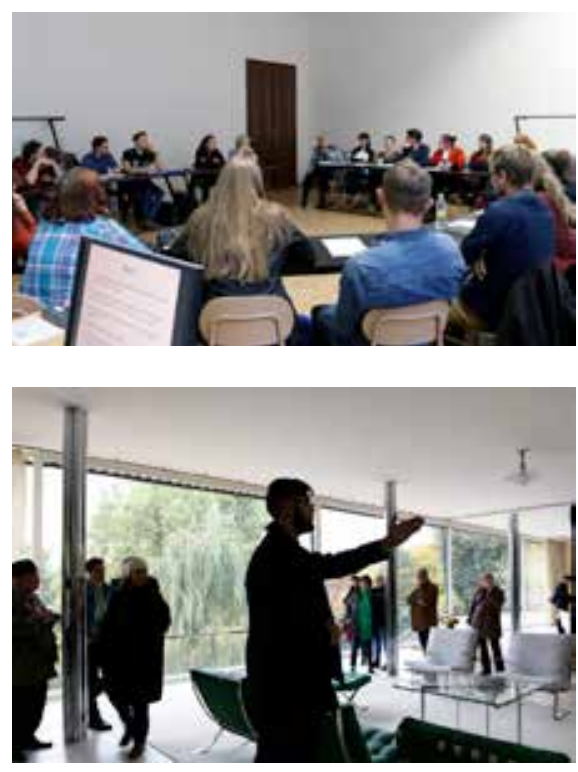

Waidacher and published in his handbook of general museology. ${ }^{5}$ He developed a museological terminology and defined thereby the state of research. Until today, the Department of History, University of Graz, is the only department in a faculty of arts and humanities in Austria where courses in General Museology have been offered since the early 1990 s as a part of the degree programme "Applied Cultural Studies". ${ }^{6}$ According to this, the relations between Brno and Graz have a long-lasting tradition dating back to scientific exchanges

\footnotetext{
5 WAIDACHER, Friedrich. Handbuch der allgemeinen Museologie. 3rd ed. Wien, Köln, Weimar: Böhlau, 1999.

6 Official homepage - see Studienschwerpunkt Kulturmanagement. In Karl-Franzens-Universität Graz [online]. [cit. 2017-03-13]. Available from www: <https://geschichte.uni-graz.at/de/ allgemeine-geschichte-der-neuzeit/lehre-studium/ studienschwerpunkt-kulturmanagement/>.
} 
between Zbyněk Z. Stránský and Friedrich Waidacher. The following project report draws on these basic museological concepts and focuses on current museological relations between Masaryk University and University of Graz as exemplified by a project titled "Open round table of museology", 7 in order to show that long-lasting traditions of scientific exchanges are resumed and thereby also integrating museology students.

The project idea goes back to a large international conference Muzeo50 $0^{8}$ celebrating the $50^{\text {th }}$ anniversary of the beginning of museology tuition at Masaryk University in Brno, which was organized by Masaryk University in Brno in November 2014. In the context of this conference, special questions arose on the "usability" of museology in theory and practice of exhibition-making, and on the need of informational and professional interconnecting of museological and academic institutions, and promoting of their cooperation in the field of scientific development of museology as a discipline. There is a need to strengthen the connection between these institutions towards popularisation of professional protection, conservation and care for movable heritage, as well as methodical and educational help and transfer of knowledge among museological institutions, museums and public authorities. In effort to discuss these topics in more detail, the idea arose of bringing together students and senior scientists. This activity should also strengthen the

\footnotetext{
7 See Open Round Table of Museology 2016. In UNESCO Chair of Museology and World Heritage [online]. Masaryk University, Faculty of Arts [cit. 2017-03-13]. Available from www: <http://www. phil.muni.cz/wune/home/projekty-a-pilotniaktivity-1/open-round-table-of-museology-2016/

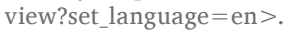

8 See Muzeo50 - International Museological Conference. In Masaryk University [online]. [cit. 2017-03-13]. Available from www: <https:// www.muni.cz/en/events-calendar/archive45466549?lang $=$ en $>$.
}

discipline's background and it could lead to new insights for practical implementation of museological theory. In order to realise this plan, museology students should come together to discuss special topics within a round table and to critically reflect and discuss them with senior scientists. Therefore a project titled Open Round Table of Museology was planned as a part of the UNESCO Chair of Museology and World Heritage activities: Museology - a way to protect and raise the public awareness of culture-historical heritage. This project should also strengthen the cooperation between two project partners - Masaryk University and University of Graz, and it was intended to establish the tradition of round tables as a response to modern trends, current needs and scientific development of museology as a discipline. For the first Open Round Table of Museology project topic was chosen which is considered crucial for museology students at both universities Theoretical foundations of museology for practical implementation in modern museum work - and a structured system of activities dealing with the topic in various ways also was built. The main goal was to make the students think critically of their possibilities, to make them work with museological theory, to connect it with their own experiences from museum work and to make them create their own opinion on the problem. This should be done by their own research activities, including educational activities, international group work and students-experts discussion. The Open Round Table of Museology project was not only targeted on students, but wanted to involve museum professionals as well. That is why a part of the Open Round Table of Museology meeting - the lectures of Graz and Brno museologists and the final round table discussion - were open to general public and to museum professionals and organisations such as ICOM Czech Republic.

In the first preparatory phase, teaching activities at universities in Graz and Brno were carried out. During spring semester 2016, students in $\mathrm{Graz}^{9}$ were made acquainted with theoretical concepts and the system of museology, also referring to the international state of research as well as to the profile topic of the Open Round Table. Theoretical foundations of museology were revised and adjusted for practical implementation in modern museum work. The same was done within a course taking place at Masaryk University in Brno in early autumn $2016 .^{10}$ These preparatory activities were aimed at the main project phase with a meeting of Austrian and Czech students at Masaryk University in Brno. To fulfil this aim, 10 Austrian students and 2 Austrian senior scientists travelled to Brno for four days. ${ }^{11}$ Before coming together, all of the students had to work with selected museological literature referring to the main topic of discussing the relevance of museology in the context of modern museum work, they had to define their own point of view and find out other sources to support their opinion. The four-day Open Round Table of Museology meeting took place

\footnotetext{
9 Given by Bernadette Biedermann; see the University of Graz course programme online: Museology II (Theoretical Museology): Lehrveranstaltung - Detailansicht. In Karl-Franzens-Universität Graz [online]. [cit. 2017-03-13]. Available from www: <https://online.uni-graz.at/kfu_online/ wbLv.wbShowLVDetail?pStpSpNr $=415772 \&$ pSpracheNr $=2 \&$ pMUISuche $=$ FALSE $>$

10 Given by Lenka Mrázová; see the Masaryk University course programme online: Forum of Museology. In Masaryk University Information System [online]. [cit. 2017-03-14]. Available from www: $<$ https://is.muni.cz/predmet/phil/autumn2016/ MUI_338?lang $=$ en $>$.

11 The journey and stay were supported by the project „AKTION - Österreich - Tschechische Republik“. For the German version of the official website see: http://www.dzs.cz/de/aktion-osterreich-tschechische-republik/stipendien/; for the English version see: http://www.dzs.cz/en/ [cit. 2017-03-13].
} 
at Masaryk University and had a timetable full of activities like workshops, excursions, lectures and in the end an intensive discussion lasting more than two hours.

In the first morning of the meeting, Austrian and Czech museology students came together in a student workshop, were matched at random to compare their points of view and to make common ground for the round table engagement. Therefore each group allocated one topic, which arose from teaching activities connected to the project at both universities, and dealt either with the meaning of museology in the context of cultural theories and heritology, or with the relevance of "memory“ and "history" in the context of museums, or with the meaning of museology in the documentation process and the relevance of museality in the context of museum education and museum pedagogy. These reflections were based on theoretical texts ${ }^{12}$ and deepened by

12 Literature selected by Bernadette Biedermann and Lenka Mrázová: STRÁNSKÝ, Zbyněk Z. Museology as a Science. Museologia, 1980, vol. XI, no. 15, pp. 33-40. ISSN 0392-5528; MACDONALD, Sharon. Memorylands. Heritage and identity in Europe today. London, New York: Routledge: 2013. ISBN 978-0-415-45334-9 (pbk); DESVALLÈES, Andre and Francois MAIRESSE (eds.). Key Concepts of Museology [online]. Paris: Armand Collin, 2010, pp. 53-56 [cit. 2016-09-06]. Available from www: $<$ http://icom.museum/fileadmin/user_upload/ pdf/Key_Concepts_of_Museology/Museologie Anglais_BD.pdf $>$. ISBN 978-2-200-25398-1. Literature selected by Marlies Raffler:

HAAG, Sabine and Gudrun SWOBODA (eds.)

Celebratrion! Feste Feiern. 125 Jahre -

Jubiläumsausstellung. Exhibition Catalogue 8

March - 11 September 2016. ISBN 978-3-99020-

-110-7. RIVERA-ORRACA, Lorena. Are museums

sites of memory? The New School for Social

Research. In The New School Psychology Bulletin,

vol. 6 , no. 2, pp. 32-37. ISSN: 1931-7948 (online)

(ISSN print: 1931-793X). RADCLIFF-UMSTEAD,

Giulio Camillo's emblems of memory. In Yale

French Studies, no. 47, Image and Symbol in the

Renaissance (1972), pp. 47-56. ISBN 10: 84-399.

-0257-3/ISBN 13: 978-84-399-0257-7.

Literature selected by Nikolaus Reisinger:

BENJAMIN, Walter. The Work of Art in the Age of

Mechanical Reproduction. 1936. Available online:

https://www.marxists.org/reference/subject/

philosophy/works/ge/benjamin.htm [cit. 2017-

$-03-13]$ lectures given by senior scientists ${ }^{13}$ as well as by museological excursions. ${ }^{14}$ An educational excursion to Vila Tugendhat was focused on using the theory of museology in practical museum work, as exemplified by Vila Tugenthat and its successful reconstruction and preservation as a part of Brno City Museum. The main activity was of course the meeting of students and senior scientists ${ }^{15}$ at a round table which was titled Theoretical foundations of museology for practical implementation in modern museum work. Student groups presented their statements and questions they have dealt with and were faced with opinions of other project groups and academic museologists. The goal of the discussion was to give space to students' opinions, motivate them to personal engagement in the topic and to give them professional feedback at the partner level of debate.

The first group ${ }^{16}$ dealt with the meaning of museology in the context of cultural theories and heritology and referred thereby to several definitions of museology in international debates. ${ }^{17}$ In

13 See the programme online: http://network. icom.museum/fileadmin/user_upload/minisites/ icom-czech/pdf/konference_tuzemske/2016 Open_round_table_UNESCO_Chair_Brno.pdf [cit. 2017-03-13].

14 To Vila Tugendhat: http://www.tugendhat.eu/ de/ [cit. 2017-03-13] and Špilberk Castle: http:// www.spilberk.cz/en/ [cit. 2017-03$-13]$.

15 Lenka Mrázová, Bernadette Biedermann, Marlies Raffler, Otakar Kirsch, Lucie Jagošová.

16 Student participants in the project were Czech students Matej Bášti, Tereza Doubková, Monika

Hadová, Lucie Houzarová, Dominik Jančev, Pavel Janek, Milan Janota, Lucie Jaslovská, Kristýna Krupková, Anna Machová, Lukáš Néger, Lucie Sušilová, Tímea Simková and Austrian students Dominik Augustinovic, Nina Bachler, Franz Gregor Dörfler, Lukas Fladl, Christopher Pollin, Katharina Prietl, Markus Trummer, Alfred

Weinmann, Marlene Weinzettl and Sabine

Margarethe Zambo. During the project meeting students worked in mixed groups.

17 See DESVALLÈES, Andre and Francois MAIRESSE (eds.). Key Concepts of Museology [online]. Paris: Armand Collin, 2010, pp. 53-56 [cit. 2016-09-06]. Available from www: <http://icom. museum/fileadmin/user_upload/pdf/Key_Con- this context several questions and points for discussions were developed. The group was of the opinion that we have to strengthen the theoretical basis and to combine the basis more and more with applied aspects of museum work which would be especially important for the communication process. This could lead to a process of reflecting theories and maybe change them if afforded to be applied to practical implementation.

The second group focused on the relevance of memory and history in the context of museums and in relation to the concept of museum pedagogy. The group was instructed to deal with three selected memory institutions, which were the anniversary exhibition at the Kunsthistorisches Museum Wien, the Haydn-Haus Eisenstadt and especially exhibiting a genius and the Titanic Belfast. Referring to their statement, the group discourse was about the responsibility of exhibition authors concerning the angle of perspectives and the selection of objects. This aspect was combined with the question of ethical aspects. From a museological point of view, the concept of museality can present a way out of this discussion. This expression of a special relationship between man and reality is attributed to objects which stand as witnesses to special circumstances, persons and facts. The main point is that objects as witnesses are able to touch the heart of visitors and to affect them emotionally. The main question arising in this context is, whether museality is the main quality of the object or whether it can also be defined as a part of each of us?

cepts_of_Museology/Museologie_Anglais_BD.pdf > . ISBN 978-2-200-25398-1. 


\section{EXAMPLE OF STUDENT WORK}

\section{The anniversary exhibition at the} Kunsthistorisches Museum Wien

In 2016, the Kunsthistorisches Museum Wien celebrated the 125 th birthday of the main building. In addition to the small anniversary exhibitions, the large special exhibition "Feste Feiern" (Celebration!) treated various early modern festivities with the help of 126 objects. It was therefore decided not to celebrate the institution by presenting its most famous and popular objects, but to show different kinds of festivals. The chosen theme of the exhibition resulted in presentation of these ephemeral spectacles with illustrations of festivities, artefacts and armour, as well as pieces of music and props such as a 17th century rocket-stick and a Stechsack. Thus, the special exhibition differed from the usual art-historical exhibitions by its culture-historical topic and through the object selection.

\section{Haydn-Haus Eisenstadt and exhibiting a genius}

The composer owned the baroque Haydn-Haus in Eisenstadt for 12 years. Today it is used as a museum showing the private Haydn. It was tried to recreate the atmosphere of the period with original furniture of that time. The exhibition presents original portraits of Haydn, some of his personal letters and music pieces as well as belongings of friends.

Our group dealt with the question whether it is possible to exhibit the "genius" Haydn, or whether it is only possible with the composer's musical work, since it represents his mind. In Eisenstadt it was thought that it was possible and that two museums were needed. Although the city played an only insignificant role in the life of Haydn, the Haydn-Haus and the Esterházy Palace have a Haydn exhibition, because the composer and his music drag many visitors to the region. There also are good museological reasons for such exhibitions: By combining Haydn's music with various objects and using various media, a more intensive subject-object communication can be established for which his biography offers the framework. However, in the case of the Haydn-Haus, it's impossible to exhibit the entire life of the musician with the building and the objects in the museum. There are just too few personal items in the museum and the house was rarely inhabited by him.

\section{Titanic Belfast}

Titanic Belfast opened its doors in 2012 to the centenary of Titanic's maiden voyage. It is a monument to the maritime heritage of Belfast and it houses a museum dedicated to Titanic. The building stands in Titanic Quarter, a waterfront regeneration with historic maritime landmarks. Here the shipyard Harland and Wolff, at the time the largest shipyard in the world, built the Titanic and its sister ships. Back then, the company was employer of many inhabitants of Belfast. The two iconic twin shipbuilding gantry cranes Samson and Goliath, owned by Harland and Wolff, still dominate the Belfast skyline and are landmark structures of the city. The shipyard, which has been in economic decline since the 1960s, had to sell the area at the beginning of the new millennium in order to restructure itself and save the 500 remaining jobs.

The original plan was to build a maritime heritage museum, but in 2005 the project of a Titanic Museum was announced to attract tourists to the area. The expected annual 450,000 visitors were clearly exceeded in the first year: 800,000 visitors came, of which 470,000 were from outside Northern Ireland. These figures as well as the 2016 awarded title "Europe's Leading Tourist Attraction" testify to the success of the tourist concept.

The exhibition has been conceived as a multimedia "Titanic experience" which is achieved through the use of various media such as odours, video and sound installations, as well as episodes of the history of Titanic and Belfast. In addition to this interaction of the exhibition with the senses of visitors, preconceived opinions are addressed by dealing with the pop-cultural impact of the Titanic. Of course, the Celine Dion song and the James Cameron film also are included in this part of the exhibition.

In order to generate the highest possible profit, the building also is used as a venue. It was discussed whether the celebration of weddings in the building is an ethical problem. The group was of the opinion that one cannot accuse Titanic Belfast of making money at the expense of the Titanic tragedy. The advertising material for the wedding events speaks neither of the sinking, nor of the 1997 Titanic film. Instead, a modern and slightly nostalgic, luxurious environment is advertised. The marketing of Titanic Belfast can' t be compared to consumerism of the Titanic museums of Pigeon Forge, Tennessee and Branson, Missouri, which seem to cross the fine line between good and bad taste.

The third group was dealing with The meaning of museology in the documentation process and additional themes relating to Aura - defined by Walter Benjamin, and function of aura in the world 


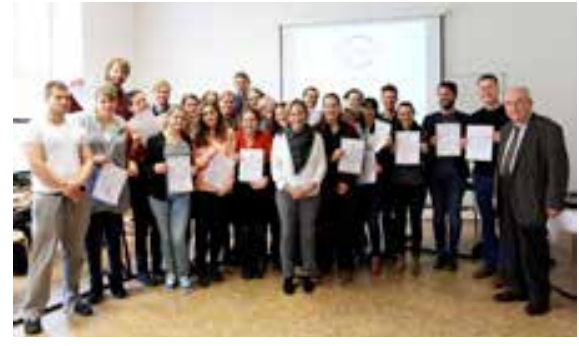

of museology. The round table discourse referring to the presented statement of the relevance of museum documentation referring to Benjamin's aura was about the question whether the process of digitization of objects adds a "new" aura to objects. Of course, places, presentations and persons do have an aura, too. Moreover, the question arose whether digital representations of objects have an own aura? And furthermore, if in the context of museum exhibitions, is it of relevance whether the objects presented are "real" or whether they are replicas? Within this discourse, synonyms for "aura" were created - the "spirit", the "presence" and the "power" of objects. Finally, museology could help visitors to "feel" the aura of an object, to get in touch with it by making use of tools.

\section{EXAMPLE OF STUDENT WORK}

Our group which consisted of Czech and Austrian students was put in front of a few simple but at the same time complex questions which needed answers that overlapped with other disciplines like philosophy, history, psychology and some others.

In overall discussions, everyone in our circle added his or her insight and ideas to determine what the documentation process actually is, what it should cover and what the role of museology in this context should be. We came to a conclusion (and later it was agreed on and extended in the last Round Table discussion) that it consists of three main parts: the care of the artefact, defining museality and finding wider contexts of objects as well as exhibiting them.

For finding the best way of how to take care of the artefacts we have to understand what they want to tell us. We understand them as witnesses to past times that can tell us stories but at the same time they are like a material vessel on which we can find all the information they can give us - like the material and technologies, the process of decaying, the "style" in which the object was made, so that we can "label" it and confine it to proper eras of human history. The knowledge of all this information can help us to create best conditions for keeping our musealia so that they can last as long as possible and provide us with possible answers or context information waiting for those, who know what to look for and who will examine them in the right way.

For a museologist it will mean that except the basic skill of looking for context he/she has to know how to handle museum objects properly to avoid preventable damage, how to store them, because most of the materials have their special needs, or how to recognize whether the condition of artefacts is demanding restoration. However, one of the most important abilities should be the knowledge of the nature of the objects, their material and its limits, and it will be all underlined with basic capabilities of using laboratory tools like microscope, humidity meters etc.

Therefore, museology gives an important input to the process of researching objects. Furthermore, the possibilities of modern communication and technology can provide us not only with a "Global Virtual Museum", where a visitor of the website from anywhere in the world can examine the works of art in high detail pictures or other sort of media. Additionally, it would create an ultimate library for research based on comparison. At this point it would make a great background for widening any part of museology. We believe that competent museologists can enhance and accelerate any research with expert examination and sending the output information via internet, saving a possible worldwide journey to see objects in reality, although the "aura" of an artefact has to be experienced in its presence. The secondary benefit would be that at least some records of artefacts could be saved in the case that fate will be unkind to them; for example, the destruction and plundering of museums in Iraq after which a lot of cultural heritage is lost, as well as other sad examples.

The third major part of this question is the exhibiting of objects. With the use of modern technologies there is an effective way to search for context but, on the other side, it offers us multiple tools for better ways of exhibiting and presenting museum objects. For example, various projections accompanied by sound, use of interactive touchpads or objects to touch, so that the visitors of museums or exhibitions can gain more experience or have a chance to better comprehend the information or context of exhibited musealia. It is a tiny fraction of the ways how to make the story of the artefacts more attractive to the public, so that they will be more willing to visit museums to explore new facts about our past, presence and possible future. But at this point we are touching the field of question covered by another group, who was discussing the importance of museology in education process. 
Aura- discussion based on definition by Walter Benjamin and its function in museology

At first, we wanted to determine in our own words what aura is, and in the second step we compare it to the ideas by Walter Benjamin. The group came to the conclusion that it is an ability of every object which is unmeasurable by today's technology, it is immaterial and its strength is dependent on two main determinants: the context of an artefact and the sensitivity of observers towards the artefact. So we can, for example, picture an imaginary encounter of viewers with the cross, which was supposed to be a tool of the martyr of a saint. For somebody it could cause a spiritual experience of getting in presence of such a relic but for somebody else it could be just a crude wooden cross with nothing interesting about it.

The strength of an object's aura is also connected with rarity and uniqueness of the artefact which interacts with the emotional perception of observers. For huge architectonic structures and monuments it is easy to emanate an aura and evoke awe or other reactions. For example, the incredible mass and age of the Pyramids of Giza can draw the thoughts of visitors to their futility in the passage of time. But how does aura work with smaller objects or artefacts? Can it be created? And if so, can it be faked?

At this point, our own opinions will merge with those by Walter Benjamin, although his opinions are tainted by the era of art-deco when he was defining them. During the art-deco movement, which had high expectations for progressively evolving technology, having the force to save the mankind for a bright future. On the other hand, Walter Benjamin had seen the huge propaganda potential of the newborn phenomenon of photography and cinematography. We agree that aura is not separable from the artefact because it is connected to its material and presence. This is why its impact is always somehow diluted when the artefacts are copied or broadcasted in any way. Here W. Benjamin points out why the auras of actors are boosted by the "cult of personality" provided additionally by other media. It means that to experience aura, the observer has to come to the presence, to the near vicinity of the artefact.

But these ideas become more complex and less straightforward when we start thinking about the copies of the objects. Can the aura be faked? A material for thought can be an example of magnificent ancient remnants of the statue of Laocoön and his sons, which is depicting the wrath of gods sent on the prophet of Troy in the shape of sea snakes, so he couldn' $t$ warn that the Troy horse is a trap. This statue is a real antique and its creation dates back to a deep past but this statue is only a copy of an older original which probably did not survive until present. So, we can still experience its beauty and as an observer we can extract the information or the story contained in this masterpiece. The same difficulties can raise when we will weigh the authenticity of the works of art created like copies by the help of original moulds for statues or engraved plates for prints.

Now the course of the discussion will turn to the meaning and practical use of aura in museology. As we are aware that the strength of the aura depends on rarity and exclusivity of an artefact in connection with its context, we can glimpse the possible way of how to present the exhibits with the true and appealing story or to determine which of the artefacts has the biggest potential to bring the visitors to see it. Then it is the work for an exhibition designer to highlight these rarities so that they can have the strongest possible impact on visitors.

This ability to enjoy the visual beauty and context of museum objects has to be fostered in museum visitors, and we as museologists should create the best possible environment for further refinement of observing capabilities of the visitors with a wide array of demands. This probably is one of the biggest tasks that the presentday museum education has to tackle.

The fourth group statement on museum pedagogy referred to the second group and pointed out the difference between museums and schools. Naturally, the basis for museum education should always be a museum object which underwent the process of musealisation. Within the round table discussion several exhibition examples from Brno and Graz were analysed.

Finally, Brno City Museum at Špilberk Castle was visited to discuss the reflected topics with the authors of a temporary exhibition on the topic of television in Brno. In conclusion, the last phase included the preparation and publication of a report on the project to document the meeting. The report is available to the international scientific community in the Museologica Brunensia journal. A common summary of the project activities represents the basis for the tradition of round tables of museology as a response to modern trends, current needs and scientific development of museology as a discipline. On the basis of the project, public educational lectures were prepared for publishing to make a part of the Open Round Table of Museology 
available to the whole museological community.

The activity of organizing a round table offered the missing space for encounters, sharing of knowledge and information, and space for active project cooperation on the joint topic of development of museology and museums which should strengthen the discipline of museology by bringing together students and senior scientists in the given field. The Open Round Table of Museology motivated the students to their own scientific engagement and experience of international cooperation and scientific meeting and built the tradition of international academic scientific meeting in the field of museology. It strengthened the contacts and collaborations among students and defined the knowledge and inspiration of a successful implementation of museum theory in practical museum work. New knowledge for students was generated and it was possible to compare the opinions by various senior scientists.

To turn this programme into reality, synergies of the museological centres in Brno (museum education and pedagogy) and Graz (history of the museum phenomenon and theoretical museology) were used and, furthermore, the scientific relations between Brno and Graz were resumed and strengthened. These relations will be further developed in the autumn of 2017 by organizing another round table at the University of Graz, where junior and senior scientists will come together to develop further the process of interpretation in museology and modern museum work.

The activities of the Open Round Table of Museology were supported by AKTION Czech Republic Austria, science and education partnership, and by the Brno City Museum as an excursion partner.

\section{REFERENCES:}

AKTION - Österreich - Tschechische Republik [online]. [cit. 2017-03-13]. Available from www: <http://www.dzs.cz/en/aktion-czech-republic-austria/>.

Dept of Archaeology and Museology - the Museology Section [online]. Masaryk University, Faculty of Arts [cit. 2017-03-14]. Available from www: <http://www. phil.muni.cz/waom/index_html-en/ view? set_language $=$ en $>$.

Forum of Museology. In Masaryk University Information System [online]. [cit. 2017-03-14]. Available from www: <https:// is.muni.cz/predmet/phil/autumn2016/ MUI_338?lang $=$ en $>$.

Muzeo50 - International Museological Conference. In Masaryk University [online]. [cit. 2017-03-13]. Available from www: <https://www. muni.cz/en/events-calendar/archive-45466549? lang $=$ en $>$.

Museologica Brunensia, 2016, vol. 5, no. 2. ISSN 1805-4722 (print), ISSN 2464-5362 (online).

Museology II (Theoretical Museology): Lehrveranstaltung - Detailansicht. In Karl-Franzens-Universität Graz [online]. [cit. 2017-03-13]. Available from www: $<$ https://online.uni-graz.at/kfu_online/wbLv.wbShowLVDetail?pStpSpN$\mathrm{r}=415772 \&$ pSpracheNr $=2 \&$ pMUISuch$\mathrm{e}=$ FALSE $>$.

NASH, Susanne. The UNESCO Chair of Museology and World Heritage: Mrs. Suzanne Nash's memories of the origins of the UNESCO Chair of Museology and World Heritage and of the first UNESCO Chair holder Vinoš Sofka. Museologica Brunensia, 2015, vol. 4, no. 2, pp. 72-73. ISSN 1805-4722 (print), ISSN 2464-5362 (online).

Open Round Table of Museology 2016. In UNESCO Chair of Museology and World Heritage [online]. Masaryk University, Faculty of Arts [cit. 2017-03-13]. Available from www: <http://www.phil. muni.cz/wune/home/projekty-a-pilotni-aktivity-1/open-round-table-of-museology-2016/view?set_language $=\mathrm{en}>$.
Studienschwerpunkt Kulturmanagement. In Karl-Franzens-Universität Graz [online]. [cit. 2017-03-13]. Available from www: <https://geschichte.uni-graz.at/ de/allgemeine-geschichte-der-neuzeit/ lehre-studium/studienschwerpunkt-kulturmanagement/>.

UNESCO Chair of Museology and World Heritage [online]. Masaryk University, Faculty of Arts [cit. 2017-03-14].

Available from www: <http://www.phil. muni.cz/wune/index_html-en/view?set_language $=e n>$.

WAIDACHER, Friedrich. Handbuch der allgemeinen Museologie. 3rd ed. Wien, Köln, Weimar: Böhlau, 1999. ISBN 978-3-205-99130-4.

\section{BERNADETTE BIEDERMANN}

Department of History, University of Graz, Austria

\section{LENKA MRÁZOVÁ}

Department of Archaeology and Museology, UNESCO Chair of Museology and World Heritage, Masaryk University, Brno, Czech Republic 